\title{
PERMAINAN KOOPERATIF DAN KEMAMPUAN KOMUNIKASI DENGAN TEMAN SEBAYA PADA ANAK PRASEKOLAH
}

\author{
Riza Noviana Khoirunnisa ${ }^{1}$
}

Universitas Negeri Surabaya

\begin{abstract}
Abstrak
Penelitian ini bertujuan untuk mengetahui efektifitas permainan kooperatif untuk meningkatkan komunikasi dengan teman sebaya pada anak prasekolah. Penelitian ini merupakan penelitian eksperimen kuasi dengan desain non randomized pretest posttest control group design. Subjek penelitian yang terlibat dalam penelitian ini adalah anak pra sekolah usia 5 tahun sebanyak 15 siswa pada kelompok eksperimen dan 15 siswa kelompok kontrol. Alat pengumpul data berupa checklist observasi yang digunakan untuk mengukur komunikasi dengan teman sebaya pada anak prasekolah. Analisis data dilakukan dengan statistik parametrik menggunakan uji t. Komunikasi dengan teman sebaya menunjukkan peningkatan dengan nilai t sebesar 18,757 dengan signifikansi sebesar 0,000, dan effect size termasuk kategori besar yaitu 64,03. Berdasarkan hasil analisis data tersebut, permainan kooperatif efektif meningkatkan komunikasi dengan teman sebaya pada anak prasekolah.
\end{abstract}

Kata kunci: anak prasekolah, komunikasi dengan teman sebaya, permainan kooperatif.

\begin{abstract}
The purpose of the research is to know the effectiveness of cooperative games to improve communication skills with peers in preschoolers. The research is quasi experimental research with non randomized pretest posttest control group design. The research subjects are fifteen children of five years old preschoolers in experimental group and so does the control group. The instrument of the research is observation checklist which is used to measure the ability of preschoolers' communication with peers. Analyzing data was done by statistical parametric using t-test. Communication with peers showed the improvement with t-test 18,757, 0,000 level of significant and the effect size are 32,85 which is categorized to big, 64,03. Based on this result, cooperative games is effective to improve communication skills with peers in preschoolers.
\end{abstract}

Keywords: preschoolers, communication with peers, cooperative games.

1'rizanoviana@gmail.com

Jurusan Psikologi Universitas Negeri Surabaya

Lidah Wetan, Lakarsantri, Surabaya

Psikosains, Vol. 13, No.2, Agustus 2018, hal. 93-108 


\section{Pendahuluan}

Periode anak merupakan salah satu periode dalam tahap perkembangan yang menentukan keberhasilan anak dalam melewati periode perkembangan selanjutnya. Cohen \& Rudolph (1997) (dalam Hidayatin, 2010) mengungkapkan bahwa anak yang menginjak usia prasekolah, berkembang kemampuan untuk mengidentifikasi dunia di luar dirinya, kesiapan untuk berbagi, serta berkurangnya ketergantungan terhadap orang dewasa untuk memberikan petunjuk dan juga untuk memenuhi kebutuhan mereka akan pertemanan, saat di mana anak-anak siap untuk berhubungan satu sama lain.

Karakteristik anak prasekolah antara lain meliputi perkembangan motorik anak prasekolah yang semakin matang sehingga memungkinkan anak bergerak lebih aktif, perkembangan bahasa \& kognitif anak yang mampu berkomunikasi dan mengerti dunianya serta egosentrisme anak akan berkurang dengan bertambahnya usia dan kefasihan berbicara, perkembangan sosial anak meningkat yang memiliki pergaulan lebih luas dan anak mulai memperlajari dasar-dasar perilaku sosial sebagai persiapan kehidupan sosial yang lebih tinggi. Menurut Ediastri (dalam Gunarsa dan Yulia, 2010) masa anak pra-sekolah disebut juga masa kanak-kanak awal, terbentang antara umur 2-6 tahun. Ciri perkembangan pada masa anak prasekolah yaitu (1) perkembangan motorik, dengan bertambah matangnya perkembangan otak yang mengatur sistem syaraf-otot (neuromaskuler) memungkinkan anak-anak usia ini lebih lincah dan aktif bergerak, (2) perkembangan bahasa dan berpikir sebagai alat komunikasi dan mengerti dunianya, kemampuan berbahasa lisan pada anak akan berkembang karena selain terjadu oleh pematangan dari organ-organ bicara dan fungsi berpikir, juga karena lingkungan ikut membantu mengembangkannya, (3) perkembangan sosial: dunia pergaulan anak menjadi bertambah luas. Ketrampilan dan penguasaan dalam bidang fisik, motorik, mental, emosi sudah lebih meningkat dimana anak makin ingin untuk melakukan bermacam-macam kegiatan dan dihadapkan pada tuntutan sosial dan susunan emosi baru.

Sejalan dengan penelitian yang dilakukan oleh Wylie (1998) yang

menunjukkan bahwa anak-anak yang mengikuti pendidikan pra-sekolah memperlihatkan prestasi belajar yang lebih baik di sekolah dasar dibandingkan dengan murid-murid yang tidak mengikuti pendidikan pra-sekolah. Sejalan dengan pernyataan tersebut, Muijs \& Reynolds (2008:280) juga mengemukakan beberapa keterampilan kunci untuk meningkatkan kesiapan sekolah anak pra-sekolah, yaitu (1) keterampilan sosial, (seperti kemampuan untuk bekerjasama secara kooperatif, untuk menghormati orang lain, untuk mengekspresikan emosi dan perasaan dengan cara yang terhormat, untuk mendengarkan orang lain, untuk mengikuti aturan dan prosedur, untuk duduk dengan penuh perhatian, dan untuk bekerja secara mandiri); (2) keterampilan komunikasi, (seperti keterampilan untuk meminta bantuan dengan 
cara yang baik dan sopan, ketrampilan untuk menyampaikan secara verbal pikiran dan perasaan, menjawab pertanyaan terbuka dan tertutup, berpartisipasi dalam diskusi kelas, dan ketrampilan untuk menghubungkan berbagai ide dan pengalaman); dan (3) perilaku terkait-tugas, (seperti perilaku tidak mengganggu anak-anak lain selama proses belajar, keterampilan anak untuk memantau perilakunya sendiri menemukan bahan-bahan yang diperlukan guna menyelesaikan tugas, mengikuti pengarahan guru, menggeneraliasikan keterampilan ke berbagai situasi, bersikap on-task selama mengerjakan pekerjaan yang melibatkan seluruh kelas, menentukan pilihan, mengawali dan menyelesaikan pekerjaan pada waktunya tanpa pengarahan guru, dan mencoba berbagai strategi untuk mengatasi masalah yang berbeda). Anak usia prasekolah berada pada fase perkembangan bahasa secara ekspresif, anak dapat mengungkapkan keinginannya, penolakannya maupun pendapatnya dengan menggunakan bahasa lisan yang sudah dapat digunakan anak sebagai alat berkomunikasi (Susanto, 2011).

Hasil pengamatan dan wawancara dengan sejumlah guru TK di Surabaya menunjukkan bahwa aktifitas belajar yang dilakukan berupa membaca, menulis mewarnai, menggambar dan kegiatan penunjang seperti komputer, bahasa inggris, bimbingan agama, melukis, menari dan memasak. Pada aktivitas-aktivitas tersebut memang membantu anak mengembangkan kemampuan berpikir, namun kesadaran guru untuk melatih komunikasi dengan teman sebaya masih rendah dan yang menyebabkan siswa tidak memiliki ruang yang cukup dalam berekspresi sehingga siswa menjadi pasif dan bergantung pada guru. Hal ini disebabkan karena semua keperluan siswa dan kesulitan yang dirasakan siswa diselesaikan oleh guru dari pada guru mengajak siswa lain untuk menyelesaikan kesulitan bersama-sama. Guru yang memberikan solusi atas masalah yang dihadapi siswa tersebut mengambil jalan pintas karena tidak terlalu membutuhkan banyak waktu, karena apabila guru mengajak siswa lain untuk bersama-sama menyelesaikan masalah akan membutuhkan banyak waktu. Beberapa guru menyatakan bahwa sekolahnya menerapkan model pembelajaran terpusat pada siswa, tetapi pada penerapan di lapangan guru sangat aktif dan siswa pasif yang menjadikan siswa memiliki ketergantungan dengan guru.

Bahasa merupakan faktor utama dalam melakukan komunikasi. Tahap perkembangan bahasa terdiri dari usia 1-2 tahun, anak mulai belajar nama dan merekam benda maupun kejadian yang dialami dan anak mulai mampu mengucapkan dua kata; 3-5 tahun, anak mulai berpikir abstrak, mulai mampu menghubungkan keterkaitan yang ada di lingkungannya serta mampu menyusun kalimat dari S-P-O. Vygotsky (dalam Susanto, 2011) mengemukakan tentang prinsip zone of proximal, yaitu zona yang berkaitan dengan perubahan dari potensi yang dimiliki oleh anak menjadi kemampuan actual (Seefeld dan Barbour, 1994), maka prinsip-prinsip perkembangan bahasa anak usia taman kanak-kanak adalah 
interaksi anak dengan lingkungan di sekitarnya, membantu anak memperluas kosakatanya dan memperoleh contoh-contoh dalam menggunakan kosakata ini secara tepat dan mengekspresikan kemampuan bahasa. Ekspresi kemampuan bahasa anak dapat disalurkan melalui pemberian kesempatan pada anak untuk mengungkapkan pikiran dan perasaannya secara tepat.

Komunikasi dengan teman sebaya pada anak prasekolah ini merupakan gagasan yang disampaikan anak pada temannya sebagai mitra yang interaktif kemudian diberikan suatu umpan balik atas gagasan tersebut. Komunikasi dengan teman sebaya mampu mengidentifikasi komunikasi anak-anak dalam upaya untuk mengkoordinasikan perilaku dengan teman sebaya (Cooper ,1980 ; Howes, 1985; Howes dan Unger, 1992; Gauvain \& Rogoff, 1989).

Komunikasi dengan teman sebaya meningkat selama tahun-tahun prasekolah. Anak usia tiga tahun dan empat tahun bermain bersama untuk mengidentifikasi berat balok yang sama. Anak usia empat tahun berhasil pada tugas ini. Ia mengajukan pertanyaan pada teman sebaya, menjelaskan tugas atau tindakan yang dilakukan pada teman sebaya dan mengevaluasi hasil lebih sering daripada anak usia tiga tahun (Cooper, 1980).

Komunikasi dengan teman sebaya sangat diperlukan dan perlu dilatihkan sejak usia dini. Laporan statistik yang dikemukakan oleh Alisjahbana (Ayahbunda, 2001) bahwa lebih dari 13\% dari semua anak duduk di kelas satu SD (Sekolah Dasar), mereka menderita kesulitan belajar dengan presentaste tinggi untuk sosialisasi dan komunikasi 65,2\%, dan sisanya kesulitan matematika dan membaca. Berdasarkan data tersebut, mengungkapkan bahwa kesulitan komunikasi anak dan sosialisasi sebesar 65,2 \% (dalam Kibtiyah, 2003).

Komunikasi dengan teman sebaya pada anak prasekolah ini merupakan tipe dari komunikasi verbal anak prasekolah yang digunakan selama interaksi kooperatif dan bermain sosial (Howes dan Unger, 1992; Howes, 1985; Cooper, 1980; Gauvain \& Rogoff, 1989). Beberapa aspek yang diperhatikan dalam komunikasi teman sebaya menurut Howes dan Unger (1992), Howes (1985), Cooper (1980), Gauvain \& Rogoff (1989) antara lain: (1) Attention Directing / Directing, anak mengarahkan perhatian teman sebaya (seperti "Dengar," dengan menunjuk ke balok) atau kepada teman sebaya apa yang harus dilakukan, baik secara khusus maupun umum, "Jangan lakukan itu seperti itu.", (2) mengajukan pertanyaan (asking question), anak bertanya teman sebaya mengenai tugas, seperti di mana untuk menempatkan blok atau apa yang pasangan yang harus dilakukan selanjutnya, (3) menetapkan peran (Dividing Labor/ Assigning Roles), anak berusaha untuk membagi pekerjaan untuk menyelesaikan tugas atau peran pelengkap dalam kaitannya dengan tugas sebagai contoh anak membagi tugas dengan teman sebaya untuk membangun ruang sementara anak membangun dinding, (4) penjelasan (Explanations), anak menjelaskan kepada pasangan tentang tindakan anak itu sendiri, termasuk apa yang 
dia lakukan, apa yang dia lakukan, atau apa yang harus ia lakukan, seperti "Saya perlu untuk membangun dinding lebih tinggi untuk mencegah penyihir.", (5) Narasi, anak membuat pernyataan pada teman sebaya yang menggambarkan sesuatu atau yang dijelaskan. Pernyataan itu bisa saja umum atau spesifik dan terkait dengan struktur atau angka dua tersebut, seperti memegang blok dan menjelaskan untuk rekan, "Inilah pintu "atau mengumumkan kepada rekan," Kami menempatkan beberapa blok bersama-sama, (6) negosiasi (Negotiation), anak membahas dengan teman sebaya mengenai strategi pemecahan masalah atau aspek dari tugas dan berdiskusi dengan kesepakatan bersama. Teman sebaya membalas dengan setidaknya satu respon dan kemudian anak harus membuat setidaknya satu respon, untuk menghasilkan pernyataan. Respon akhir bisa menjadi sederhana seperti ya atau tidak, (7) saran / ide (Suggestions/Ideas), anak memberikan saran atau ide untuk untuk tugas, seperti cara untuk menyelesaikan tugas atau apa yang bisa dilakukan. Saran yang terlibat kemungkinan menyelesaikan tugas-tujuan yang terkait atau mengubah (mulai atau berhenti) keadaan sesuatu sebagai contoh "Kita bisa membuat sebuah garasi" dan "Mari kita membuat pintu di sini, (8) Kesepakatan/Perjanjian (Agreement), anak membuat pernyataan penerimaan atau kesepakatan dalam menanggapi tindakan seperti "ya" tanggapan dan perjanjian dengan konten yang spesifik, seperti "Ya, itu meja," dalam menanggapi narasi peer Pernyataan, "Itu meja.", (9) ketidaksepakatan (Disagreement), anak membuat pernyataan oposisi, protes, atau pembalasan dalam menanggapi tindakan, pernyataan, atau pertanyaan bahwa pasangan dibuat seperti "tidak" tanggapan dan perbedaan pendapat dengan konten yang spesifik seperti "Tidak, itu tidak pergi ke sana," setelah teman sebaya ditempatkan balok, (10) eksperimen (Experimenter), anak diarahkan mencari bantuan berupa pernyataan, pertanyaan, atau gerakan kepada eksperimenter sebagi contoh pertanyaan tentang bagaimana menyelesaikan tugas atau di mana blok tertentu harus diletakkan. Pernyataan dan pertanyaan mengenai panjang sisa waktu untuk menyelesaikan sesi yang tidak termasuk, karena tidak ada jam yang tersedia untuk anak-anak, (11) pernyataan lain yang berkaitan dengan tugas (Other task related statements), anak membuat pernyataan yang tidak spesifik tentang tugas. Hal ini termasuk pernyataan yang relevan dengan tugas atau bangunan, namun tidak termasuk dalam salah satu

Beberapa penelitian juga menemukan bahwa komunikasi dengan teman sebaya pada usia prasekolah menjadi salah satu faktor untuk memprediksi prestasi anak di sekolah. Hal ini sesuai dengan yang dikemukakan oleh Ladd, Price, \& Hart (1988) bahwa pengembangan hubungan sebaya yang positif selama tahun-tahun prasekolah telah dikaitkan dengan penyesuaian positif di taman kanak-kanak serta keberhasilan akademis dalam sekolah dasar dan sekolah menengah atas. Keterampilan narasi anak-anak sebelum masuk sekolah telah ditemukan menjadi terbaik dari hasil sekolah untuk anak-anak yang akademik dan bahasa (Paul \& 
Smith, 1993). kontekstual telah menjadi sebagai kunci penting untuk kesuksesan prestasi sekolah (Paul \& Smith, 1993; \& Lorch, 1994) salah satu prediktor beresiko pada masalah Bahasa identitas Crais

Implikasi yang didapatkan dari hambatan komunikasi dengan teman sebaya pada anak prasekolah. Anak-anak ini mengalami kesulitan berteman dan bergaul dengan orang-orang di luar keluarganya (Phalkivala, 2007) (dalam Soetjiningsih, 2012). Hal lain yang menjadi dampak dari kurangnya komunikasi teman sebaya pada anak prasekolah yaitu anak akan tersingkir "tidak memiliki teman" dari temanteman sebayanya karena ia tidak mampu bersosialisasi sesuai dengan usianya dan mereka akan mengalami kesulitan dalam menghadapi dunia sosial yang lebih luas pada jenjang pendidikan selanjutnya yaitu Sekolah Dasar (dalam Soetjiningsih, 2012).

Isu-isu yang muncul dalam penyelenggaraan pendidikan anak prasekolah akhir-akhir ini adalah pemberian materi membaca, menulis dan menghitung (3M) serta bahasa asing tanpa memperhatikan tahap perkembangan anak (Kompas (12 Juli 1997); Kompas (17 Mei 1999); Gatra (18 Desember 1999)) (dalam Astuti. 2005). Sejalan dengan pernyataan tersebut, anak usia prasekolah kurang memiliki kesempatan dalam melatih kemampuan pemecahan masalah dan komunikasi teman sebaya sehingga membuat semua aktivitas anak berada dibawah tanggung jawab guru dan guru menjadi lebih aktif sedangkan anak hanya menunggu perintah guru dalam melakukan aktivitas.

Proses pembelajaran yang terjadi kelas ditentukan oleh model pembelajaran yang digunakan oleh guru. Model pembelajaran yang diterapkan oleh guru tersebut akan menentukan hasil yang ingin dicapai. Hal ini yang menyebabkan model pembelajaran yang diterapkan merupakan fokus utama dalam keberhasilan pengajaran yang dilakukan guru.

Bermain merupakan dunia anak. Bermain mempengaruhi pertumbuhan dan perkembangan anak karena melalui bermain anak akan belajar tentang dunia sekitarnya dan belajar berkomunikasi dengan lingkungan sekitarnya terutama teman sebaya serta anak akan belajar untuk menghadapi lingkungan dengan berbagai permasalahannya sesuai dengan usianya. Vygotsky (dalam Rahardjo, 2007) berpandangan bahwa bermain bukan hanya bermakna sebagai pengembang kognitif anak, tetapi bermain juga merupakan pengalaman simbolik sosial.

Celeste (2006) mengungkapkan bahwa bermain sosial mengharuskan anak menunjukkan strategi untuk masuk ke kelompok teman sebaya, menyelesaikan konflik dan menjaga interaksi dengan anak-anak lain. Berdasarkan penelitian yang dilakukan Suminar \& Nono (2008) menyatakan salah satu strategi yang dapat diberikan dalam memberikan mainan pada anak sejak dini yaitu mengusahakan anak dalam bermain kelompok, semua anak mendapatkan peran agar terjadi aktivitas bersama dan akan mendorong anak yang pasif menjadi aktif. Usia empat

Permainan Kooperatif dan Kemampuan Komunikasi dengan Teman Sebaya pada Anak Prasekolah 
tahun sampai enam tahun, anak berminat mempelajari hal-hal baru disekelilingnya terutama interaksi terhadap teman-teman sebaya. Pada tahap ini anak memang mulai memasuki tahap bermain kooperatif, anak sudah bisa terlibat dalam permainan kelompok bersama teman-temannya, meski sering terjadi pertengkaran (Ayahbunda, 1994) (dalam Kibtiyah, 2003).

Berdasarkan penelitian-penelitian yang telah dilakukan disimpulkan bahwa bermain kooperatif lebih dapat menyediakan kesempatan bagi anak usia prasekolah untuk berkomunikasi dengan teman sebaya, diterima menjadi bagian dari teman sebaya dan mampu menyelesaikan permasalahan yang ada didalamnya daripada bermain soliter dan paralel. Komunikasi dengan teman sebaya menjadi hal mendasar dalam perkembangan bahasa, sosial dan kognitif anak prasekolah yang akan menetap hingga dewasa dan mempengaruhi keberhasilan anak melewati tahap perkembangan selanjutnya. Berdasarkan dengan temuan diatas, anak prasekolah memerlukan peningkatan dalam kemampuan komunikasi teman sebaya sesuai dengan tahap usianya.

Fenomena yang terjadi diatas adalah salah satu dari sekian banyak fenomena yang berkaitan dengan peningkatan kemampuan komunikasi dengan teman sebaya. Fenomena inilah yang melatarbelakangi perlunya penelitian mengenai bermain yang dapat meningkatkan kemampuan komunikasi dengan teman sebaya pada anak prasekolah sehingga akan dilakukan penerapan bermain kooperatif untuk meningkatkan kemampuan komunikasi dengan teman sebaya pada anak prasekolah. Penelitian ini bertujuan untuk menguji dan menganalisis efektifitas permainan kooperatif untuk meningkatkan komunikasi dengan teman sebaya.

\section{Metode Penelitian}

Penelitian ini merupakan jenis penelitian eksperimen. Penelitian eksperimen adalah penelitian yang memungkinkan peneliti memberikan perlakuan atau intervensi kepada subjek penelitian dan kemudian efek dari perlakuan tersebut diamati dan diukur (Zainuddin, 2011). Peneliti memberikan perlakuan berupa permainan kooperatif pada subjek penelitian. Subyek penelitian diberikan perlakuan dengan 2 kali pengukuran. Pengukuran yang pertama dilakukan sebelum pemberian permainan kooperatif (pre-test) dan pengukuran kedua dilakukan setelah pemberian permainan kooperatif (post-test) kepada subyek penelitian pada kelompok eksperimen dan tidak diberikan perlakuan pada kelompok kontrol.

Penelitian ini menggunakan rancangan penelitian eksperimen kuasi dengan desain ekperimen ulang non random (non randomized pretest posttest control group desain) merupakan desain eksperimen yang dilakukan dengan prates sebelum perlakuan diberikan dan pascates sesudahnya, sekaligus ada kelompok perlakuan dan kontrol dan sampel ditetapkan dengan tidak random (Latipun, 2004). 
Perlakuan dilakukan dengan penerapan permainan kooperatif, sedangkan pengukurannya dilakukan sebelum dan sesudah pemberian permainan kooperatif, yaitu dengan membandingkan antara hasil pre-test dan post-test yang telah diberikan kepada subjek penelitian

Subjek penelitian pada penelitian ini adalah anak-anak yang belajar di TK X. Populasi dari subjek penelitian ini berjumlah 40 siswa yang terbagi menjadi dua kelas. Sampel yang digunakan dalam penelitian ini berjumlah 30 siswa dengan jumlah pembagian kelas eksperimen sebanyak 15 siswa kelas dan kelas kontrol sebanyak 15 siswa sedangkan 10 siswa lainnya sebagai subjek uji coba penelitian.

Kegiatan penelitian yang dilakukan adalah memberikan serangkaian metode pembelajaran bermain sesuai dengan permainan kooperatif. Tahapan pelakasanaan antara lain (1) pre-test dimana materi tes yang digunakan untuk pre-test meliputi tugas-tugas dalam instrumen observasi komunikasi dengan teman sebaya yang terdiri dari 34 item. Pre-test bertujuan untuk mengambil data kemampuan komunikasi dengan teman sebaya anak sebelum diberi perlakuan. Tes ini diberikan kepada seluruh subjek penelitian yang berjumlah 30 anak yang dibagi menjadi 15 siswa pada kelompok eksperimen dan 15 siswa di kelompok kontrol, (2) pelaksanaan perlakuan, kelompok eksperimen diberikan perlakuan menggunakan permainan kooperatif dengan panduan modul permainan kooperatif berdasarkan teori dari Gordon \& Browne (1985) untuk anak prasekolah usia 5 tahun yang telah dikembangkan oleh penulis. Modul ini juga mendapatkan masukan dari 3 dosen, sebagai "judgement" ahli. Permainan kooperatif yang digunakan dalam penelitian ini terdiri dari tiga sesi yaitu pada sesi I menggunakan bermain memasangkan gambar dengan tulisan, sesi 2 menggunakan bermain merancang gambar dan sesi 3 menggunakan permainan lego, (3) post-test, setelah pemberian perlakuan selesai dengan pemberian materi sesuai modul, post-test dilaksanakan dengan menggunakan instrument observasi kemampuan pemecahan masalah dan komunikasi dengan teman sebaya berupa checklist.

Alat pengumpulan yang digunakan adalah insturmen observasi komunikasi teman sebaya untuk anak prasekolah usia 5 tahun. Alat ukur dikonsultasikan kepada 3 orang rater setelah dilakukan pengembangan pada bagian konstruk kemudian alat ukur digunakan pada subjek. Pengolahan data dilakukan dengan bantuan IBM SPSS statistic 24 untuk melihat efektifitas permainan kooperatif untuk meningkatkan komunikasi dengan teman sebaya akan dianalisis dengan teknik statistik uji t.

\section{Hasil dan Pembahasan}

Berdasarkan uji normalitas pada saat pre-test menunjukkan bahwa skor komunikasi dengan teman sebaya untuk kelompok eksperimen memiliki signifikansi sebesar 0,200 untuk Uji Normalitas Kolmogorov-Smirnoy dan signifikansi sebesar 0,312 untuk Uji Normalitas Shapiro-Wilk keduanya lebih besar 
dari $\alpha=0,05$ sehingga data kelompok eksperimen berasal dari distribusi normal. Uji normalitas skor komunikasi dengan teman sebaya untuk kelompok kontrol memiliki signifikansi sebesar 0,074 untuk Uji Normalitas Kolmogorov-Smirnoy dan signifikansi sebesar 0,360 untuk Uji Normalitas Shapiro-Wilk keduanya lebih besar dari $\alpha=0,05$ sehingga data kelompok eksperimen berasal dari distribusi normal.

Berdasarkan uji normalitas pada saat post-test diatas terlihat bahwa skor kemampuan pemecahan masalah untuk kelompok eksperimen memiliki signifikansi sebesar 0,200 untuk Uji Normalitas Kolmogorov-Smirnoy dan signifikansi sebesar 0,406 untuk Uji Normalitas Shapiro-Wilk keduanya lebih besar dari $\alpha=0,05$ sehingga data kelompok eksperimen berasal dari distribusi normal.

Uji normalitas skor kemampuan pemecahan masalah untuk kelompok kontrol memiliki signifikansi sebesar 0,200 untuk Uji Normalitas KolmogorovSmirnoy dan signifikansi sebesar 0,625 untuk Uji Normalitas Shapiro-Wilk keduanya lebih besar dari $\alpha=0,05$ sehingga data kelompok eksperimen berasal dari distribusi normal.

Berdasarkan hasil pengujian homogenitas diketahui bahwa data dalam penelitian ini memiliki varians yang sama pada setiap kelompok hal ini ditunjukkan dengan nilai signifikansi pada skor pre-test dan post-test kelompok eksperimen dan kelompok kontrol > 0,05 yaitu 0,290 dan 0,080 sehingga kedua kelompok tersebut dapat dikatakan homogen.

Data skor pre-test dan post-test menunjukkan bahwa data kedua kelompok normal dan homogen sehingga memenuhi uji asumsi parametrik. Uji hipotesis dalam penelitian ini dilakukan uji t. Hasil uji hipotesis penelitian adalah:

Tabel 1. Rerata Skor Komunikasi dengan Teman Sebaya pada Kelompok Eksperimen dan Kelompok Kontrol

\begin{tabular}{ccc}
\hline Kelompok & Rerata pre-test & Rerata post-test \\
\hline Eksperimen $(\mathrm{n}=15)$ & 8.27 & 30.93 \\
\hline Kontrol $(\mathrm{n}=15)$ & 9.60 & 9.60 \\
\hline
\end{tabular}

Berdasarkan hasil analisis diatas, dapat disimpulkan bahwa ada perbedaan yang signifikan antara pre-test dan post-test kemampuan pemecahan masalah pada kelompok eksperimen.

Tabel 2. Independent Sample t-test Komunikasi dengan Teman Sebaya pada Kelompok Eksperiman dengan Kelompok Kontrol

\begin{tabular}{ccc}
\hline Skor & T & P \\
\hline KTS & 19.933 & .000 \\
\hline
\end{tabular}

Berdasarkan hasil perhitungan Independent Sample T-test, diperoleh $\mathrm{t}=19,933$ dan $\mathrm{p}=0,00$ dan karena $\mathrm{p}<0,05$ maka Ha diterima, yaitu ada pengaruh 
permainan kooperatif terhadap peningkatan komunikasi dengan teman sebaya pada anak prasekolah. Perbedaan pengaruh dari kedua kelompok ini juga dapat dilihat dari perbedaan mean kelompok kontrol sebesar 9,60 dengan kelompok eksperimen dengan nilai 30,93 .

Tabel 3. Rerata Gain Score Komunikasi dengan Teman Sebaya pada Kelompok Eksperimen dan Kelompok Kontrol

\begin{tabular}{cc}
\hline Kelompok & Rerata pre-test \\
\hline Eksperimen $(\mathrm{n}=15)$ & 22.67 \\
\hline Kontrol $(\mathrm{n}=15)$ & .13 \\
\hline
\end{tabular}

Berdasarkan hasil analisis diatas, dapat disimpulkan bahwa ada perbedaan yang signifikan rerata gain score komunikasi dengan teman sebaya pada kelompok eksperimen. Perbedaan gain score sangat signifikan ini menguatkan bahwa permainan kooperatif meningkatkan komunikasi dengan teman sebaya pada anak prasekolah.

Tabel 4. Uji t Gain Score Komunikasi dengan Teman Sebaya pada Kelompok Eksperimen dan Kelompok Kontrol

\begin{tabular}{ccc}
\hline Skor & T & P \\
\hline Gain & 18.737 & .000 \\
\hline
\end{tabular}

Berdasarkan hasil hasil perhitungan paired sample t-test diatas menunjukkan bahwa terdapat peningkatan komunikasi dengan teman sebaya dangat signifikan pada kelompok eksperimen dengan nilai t sebesar 18,737 dengan signifikansi sebesar 0,000 . Nilai signifikansi lebih kecil dari $\alpha=0,05$ sehingga dari penguji ini menyatakan bahwa hipotesis diterima. Dengan demikian disimpulkan bahwa permainan kooperatif efektif untuk meningkatkan komunikasi dengan teman sebaya pada anak prasekolah.

Effect size dari permainan kooperatif terhadap komunikasi dengan teman sebaya adalah 64,03 sehingga sumbangan efektif pemberian perlakuan permainan kooperatif dalam meningkatkan skor pada kelompok eksperimen adalah besar yaitu 64,03 . Berdasarkan hasil analisis data diatas telah membuktikan bahwa penggunaan permainan kooperatif lebih efektif dibandingan dengan pembelajaran konvensional di TK X dalam peningkatan komunikasi dengan teman sebaya pada anak prasekolah.

Peningkatan komunikasi dengan teman sebaya pada anak prasekolah pada penelitian ini karena subjek diberikan perlakuan berupa permainan kooperatif. Hal ini juga dipengaruhi oleh Faktor yang mempengaruhi keberhasilan komunikasi dengan teman sebaya dalam penelitian ini antara lain, anak memahami gagasan yang dimaksud oleh teman sebaya sehingga terdapat kesamaan persepsi, anak 
memiliki pengalaman dalam berkomunikasi dengan teman sebaya akan memudahkan mereka memahami gagasan yang disampaikan oleh teman sebaya karena berkomunikasi dengan teman sebaya berbeda dengan orang dewasa, anak memberikan umpan balik seperti penjelasan, penolakan, penerimaan dan lain sebagainya serta anak memiliki kemampuan bahasa verbal dan nonverbal sehingga mereka mampu memberi umpan balik pada teman sebayanya. Hal ini sesuai dengan Howes \& Unger (1992) bahwa factor yang mempengaruhi komunikasi dengan teman sebaya pada anak prasekolah adalah memahami gagasan yang disampaikan, pengalaman, umpan balik dan kemampuan bahasa dalam komunikasi. Howes \& Unger (1992) mengungkapkan bahwa kemampuan komunikasi pada anak terbatas sehingga bermain dengan teman sebaya dapat meningkatkan komunikasi yang bermakna pada anak prasekolah. Mereka dapat mengarahkan perhatian teman sebaya pada dirinya agar teman sebaya memperhatikan apa yang akan dibicarakan atau akan dilakukan. Hal ini dilakukan dengan memanggil teman sebaya selanjutkan memegang alat permainan yang akan digunakan bersama sehingga perhatian teman sebaya dalam kelompok fokus pada satu orang tersebut. Mereka mengajukan pertanyaan pada teman sebaya mengenai apa yang akan dilakukan maupun ketika mereka tidak mengerti yang menjadi tugasnya. Mereka berusaha membagi tugas dalam menyelesaikan permainan sehingga setiap anggota kelompok memiliki peran masing-masing. Anak prasekolah memberikan penjelasan kepada teman sebayanya mengenai apa yang dilakukan. Mereka juga membuat pernyataan pada teman sebaya untuk menggambarkan sesuatu yang dijelaskan dan ketika mereka memiliki suatu permasalahan mereka membahas dengan teman sebaya untuk bernegosiasi dalam menyelesaikan permainan dengan kesapakatan bersama. Anak prasekolah dapat memberikan saran atau ide dalam menyelesaikan tugas dengan bahasa mereka sendiri sesuai dengan pengetahuan atau pengalaman yang telah mereka dapatkan sebelumnya. Mereka juga mampu membuat pernyataan penerimaan atau kesepakatan dalam menanggapi tindakan teman sebaya, dan mereka juga dapat membuat pernyataan penolakan apabila mereka tidak setuju dengan tindakan maupun ide teman sebaya. Anak juga mencari bantuan pada eksperimenter ketika dalam kelompok mendapatkan kesulitan dan setelah mereka menyelesaikan permainan mereka memberikan pernyataan yang berisi ungkapan perasaan setelah menyelesaikan permainan dengan teman sebayanya.

Berdasarkan hasil observasi komunikasi dengan teman sebaya pada saat pemberian perlakuan dapat dicapai sesuai dengan tujuan permainan yang mengacu pada aspek permainan kooperatif menurut Gordon \& Browne (1985). Hal ini sesuai dengan pendapat Cohen \& Rudolph (1997) (dalam Hidayati, 2010) mengungkapkan bahwa anak yang menginjak usia prasekolah, berkembang kemampuan untuk mengidentifikasi dunia di luar dirinya, kesiapan untuk berbagi, serta berkurangnya ketergantungan terhadap orang dewasa untuk memberikan 
petunjuk dan juga untuk memenuhi kebutuhan mereka akan pertemanan, saat di mana anak-anak siap untuk berhubungan satu sama lain. Subjek penelitian mampu memberikan gagasan kepada teman sebaya kemudian teman sebaya memberikan umpan balik atas gagasan yang disampaikan sehingga komunikasi dengan teman sebaya dapat berlangsung pada anak prasekolah sesuai dengan tujuan dalam penelitian ini. Hal ini sesuai dengan pendapat Perlmutter, Behrend, Kuo, \& Muller, (1989) bahwa anak usia lima tahun memberikan instruksi lisan benar lebih banyak dan lebih cepat daripada anak bekerja sendiri sedangkan anak usia empat tahun menghasilkan lebih sedikit instruksi lisan yang benar dan tidak lebih efisien daripada mereka bekerja sendiri dan mereka tidak lebih termotivasi maupun senang daripada anak bekerja sendirian. Komunikasi dengan teman sebaya juga mampu mengidentifikasi komunikasi anak-anak dalam upaya untuk mengkoordinasikan perilaku dengan teman sebaya (Cooper, 1980 ; Howes, 1985; Howes dan Unger, 1992; Gauvain \& Rogoff, 1989).

Subjek penelitian berkomunikasi dengan teman sebaya dalam menyelesaikan tiga jenis permainan kooperatif dalam kelompok eksperimen. Mereka menggunakan upaya komunikatif ini untuk menggali informasi tentang permainan yang akan diselesaikan bersama kelompok walaupun beberapa anak masih bertanya kepada peneliti maupun guru ketika mereka tidak memahami apa yang menjadi tugasnya. Pembelajaran yang berpusat pada siswa, siswa dituntut menjadi aktif dan guru hanya sebagai fasilitator anak sehingga ketika subjek penelitian bertanya kepada peneliti maupun guru langsung mengembalikan lagi agar ia bekerja sama dengan teman sekelompok. Guru juga menyatakan bahwa kelompok yang memiliki kerjasama baik, saling membantu dan berkomunikasi efektif dalam menyelesaikan permainan adalah kelompok yang hebat sehingga subjek penelitian kembali fokus pada kelompok masing-masing dengan berkomunikasi secara efektif dengan teman sebaya ketika perlakuan berupa permainan kooperatif diberikan pada kelompok eksperimen.

Berdasarkan hasil pengamatan bahwa merancang gambar lebih menggambarkan dengan jelas komunikasi dengan teman sebaya dibanding dengan permainan sebelumnya. Mereka berkomunikasi secara verbal dengan anak lain dan kelompok sehingga anak dapat mengarahkan perhatian, mengajukan pertanyaan, menetapkan peran, memberi penjelasan, narasi, negosiasi, saran atau ide, kesepakatan, ketidaksepakatan, bereksperimen dan memberikan pernyataan lain terkait tugas dengan teman kelompok. Hal ini sesuai dengan Hawadi (2001) yang menyatakan bahwa melalui bermain, anak menyusun kemampuan bahasanya. Banyak kosa kata muncul dari interaksinya dengan teman sebaya. Seorang anak tidak saja mengeksplorasi dunianya sendiri dengan bermain, tetapi juga bagaimana reaksi teman terhadap dirinya. Bermain sosial, ditandai dengan tuntutan untuk berkomunikasi dan negosiasi seperti ketika anak-anak harus menyepakati naskah 
dan aturan main (Bretherton, 1984; Howes et al, 1992). Dengan demikian, selama sosial bermain, anak-anak prasekolah berdiskusi, bernegosiasi, dan mengkomunikasikan ide-ide untuk mencapai bersama pemahaman tentang peran dan tema mereka masing-masing akan memberikan kontribusi pada usaha bersama (Bonica, 1993, Doyle \& Connolly, 1989, Goncu, 1987, 1993, Howes et al, 1992;. Paley, 1986).

Hasil analisis menyimpulkan bahwa setelah pemberian permainan kooperatif, semua subjek penelitian mengalami perubahan yaitu peningkatan skor komunikasi dengan teman sebaya. Permainan kooperatif termasuk jenis permainan sosial karena dalam permainan ini terjadi komunikasi dengan teman sebaya yang efektif dalam kelompok. Komunikasi yang dilakukan pada anak prasekolah terjadi secara sederhana, tidak sekompleks pada individu dewasa. Anak menciptakan variasi dalam permainan mereka karena komunikasi masih sangat sederhana (Howes \& Unger, 1992). Proses komunikasi dengan teman sebaya yang terjadi dalam kelompok dipengaruhi oleh anak mempunyai keinginan untuk berbagi gagasan dengan teman lain, anak menyampaikan gagasan pada teman secara verbal, gagasan yang disampaikan kemudian diterima oleh teman yang lain, teman memahami gagasan disampaikan, mereka mampu menerjemahkan isi gagasan yang diteruma dengan benar dan sesuai dengan harapan teman yang menyampaikan, teman memberikan umpan balik seperti pendapat, negosiasi, pernyataan setuju maupun penolakan.

Mengacu pada proses komunikasi dengan teman sebaya tersebut, anak prasekolah yang bermain bersama, mereka berkomunikasi dengan teman sebaya untuk menetapkan apa tujuan yang akan dicapai, merencanakan, memecahkan masalah, negosiasi dan mengkoordinasikan perilaku mereka untuk mengidentifikasi interaksi, mendukung permainan, dan mencapai tujuan mereka (Bonica, 1993; Connoly \& Doyle, 1984; Forys \& McCune Nicolich, 1984; Howes \& Matheson, 1992; Howes et al., 1992).

\section{Kesimpulan}

Penelitian efektifitas permainan kooperatif dengan komunikasi dengan teman sebaya pada anak prasekolah ini dilakukan berdasarkan permasalahan yang ada di lapangan. Penelitian ini menghasilkan modul permainan kooperatif yang terdiri dari tiga sesi yaitu (1) bermain memasangkan gambar dengan tulisan, dengan tujuan membina hubungan dengan anak lain dan kelompok sehingga anak dapat berinteraksi dengan anak lain dalam kelompok, (2) merancang gambar taman bermain, dengan tujuan berkomunikasi secara verbal dengan anak lain dan kelompok sehingga anak dapat mengarahkan perhatian, mengajukan pertanyaan, menetapkan peran, memberi penjelasan, narasi, negosiasi, saran atau ide, kesepakatan, ketidaksepakatan, bereksperimen dan memberikan pernyataan lain 
terkait tugas dengan teman kelompok, (3) bermain lego, dengan tujuan bekerja sama dalam memecahkan masalah bersama sehingga anak dapat menemukan masalah, mencari solusi dan strategi pemecahan masalah, menyeleksi strategi dan melaksanakan strategi yang terbaik dengan teman kelompok. Berdasarkan hasil pre test dan post test komunikasi dengan teman sebaya pada kelompok eksperimen terdapat peningkatan skor post test dan pada kelompok kontrol 13 siswa memiliki skor yang tetap pada pre test dan post test, 1 siswa mengalami peningkatan dan 1 siswa mengalami penurunan skor pre test.

Hasil efektifitas penerapan permainan kooperatif terhadap komunikasi dengan teman sebaya menunjukkan peningkatan dengan nilai t sebesar 18,757 dengan signifikansi sebesar 0,000, dan effect size termasuk kategori besar yaitu 64,03. Dengan demikian dapat dinyatakan bahwa ada perbedaan kemampuan komunikasi dengan teman sebaya sebelum dan sesudah penerapan permainan kooperatif sehingga permainan kooperatif memiliki pengaruh terhadap komunikasi dengan teman sebaya Berdasarkan hasil analisis data tersebut, permainan kooperatif efektif meningkatkan komunikasi dengan teman sebaya pada anak prasekolah.

Penelitian ini telah melaksanakan seluruh tahap penelitian. Namun, kelemahan dan keterbatasan penelitian ini masih didapati terutama pada jenis permainan yang dapat digunakan bermacam-macam, maka penelitian selanjutnya dapat mengembangkan penelitian menggunakan jenis permainan kooperatif lain dengan tujuan untuk melihat apakah ada perbedaan dalam jenis permainan yang diberikan. Jenis permainan kooperatif lain seperti balok, puzzle, bermain punggung berantai, Blind Ball, dan lain sebagainya. Penelitian selanjutnya pada orang tua memberikan kesempatan pada anak untuk bermain bersama dengan teman sebaya secara berkelompok yang terdiri dari 4-5 anak yang melibatkan interaksi, komunikasi dengan teman sebaya, dan kemampuan pemecahan masalah ketika anak berada di lingkungan rumah sehingga membangun kemampuan pemecahan masalah dan komunikasi dengan teman sebaya tidak hanya di lingkungan sekolah. Selain itum guru dapat merancang kegiatan pembelajaran dengan menggunakan permainan kooperatif yang dapat dilakukan secara berkelompok. Anggota kelompok dapat diacak sehingga anak mendapat kesempatan untuk berinteraksi dengan banyak teman.

\section{Daftar Pustaka}

Astuti, R. S. (2005). Cooperative Learning dan Pemecahan Masalah pada Anak Prasekolah. Jurnal Widya Dharma, 16 (1)

Bonica, L. (1993). Negotiations among children and pretend play. In M. Stambak \& H. Sinclair (Eds.), Pretend play among 3-year-olds (pp. 55-78). Hillsdale, NJ: Erlbaum. 
Bretherton, I. (1984). Representing the social world in symbolic play: Reality and fantasy. In I. Bretherton (Ed.), Symbolic play (pp. 3-39). New York: Academic Press.

Cooper, C.R. (1980). Developmental of Collaborative Problem Solving Among Preschool Children. Developmental Psychology. 16 (5), 433-440

Doyle, A. B., \& Connolly, J. (1989). Negotiation and enactment in collaborative pretend play: Relations to social acceptance and social cognition. Early Childhood Research Quarterly, 4, 289-302.

Forys, S. K. S., \& McCune-Nicolich, L. (1984). Shared pretend: Sociodramatic play at three years of age. In I. Bretherton (Ed.), Symbolic play: The development of social understanding (pp. 159-194). New York: Academic Press.

Gauvain, M., \& Rogoff, B. (1989). Collaborative problem solving and children's planning skills. Developmental Psychology, 25, 139-151.

Gordon, A. M \& Browne, K.W. (1985). Beginning and beyond foundation in early childhood education. New York:Delrner Publisher.

Gunarsa, S. D. dan Yulia S. D. G. (2010). Psikologi Perkembangan Anak dan Remaja. Jakarta: BPK Gunung Mulia

Hawadi, R. A. (2001). Psikologi Perkembangan Anak. Jakarta: Grasindo

Hidayati, N. (2010). Bermain Khayal untuk Mengembangkan Dimensi Sosioemosi Anak-Anak Prasekolah. INSAN, 12, 104-112

Howes, C. (1985). Sharing fantasy: Social pretend play in toddlers. Child Development, 56, 1253-1258.

Howes, C., Unger, O. A., \& Matheson, C. C. (1992). The collaborative construction of pretend: Social pretend play functions. Albany: State University of New York Press.

Kibtiyah, M. (2003) Efektifitas Cooperative Games dalam Meningkatkan Ketrampilan Sosial Anak Taman Kanak-kanak (Tinjauan Psikologis). Jurnal Studi Agama dan Masyarakat, 3 (1)

Ladd, G. W., Price, J. M., \& Hart, C. H. (1988). Predicting preschoolers' peer status from their playground behaviors and peer contacts. Child Development, 59, 986-992. 
Muijs, D. \& Reynolds, D. (2008). Effective Teaching: Teori dan Aplikasi. Yogyakarta: Pustaka Pelajar.

Paley, V. (1986). Mollie is three: growing up in school. Chicago: University of Chicago Press.

Paul, R. \& Smith, R. L. (1993). Narrative skills in 4-year-olds with normal, impaired, and late developing language. Journal of Speech and Hearing Research 36, 592 \pm 98 .

Perlmutter, M., Behrend, S.D., Kuo, F., \& Muller, A. A. (1989). Social influences on children's problem solving. Developmental Psychology, 25, 744-754.

Soetjiningsih, C. H. (2012). Perkembangan anak sejak pertumbuhan sampai dengan kanak-kanak akhir. Jakarta: Prenada

Suminar, D.R \& Nono H.Y. (2008). Eksplorasi Mainan Anak Berbasis Budaya sebagai Dasar Penyusunan Strategi pemberian Stimulasi bagi Anak Sejak Dini. (Laporan Penelitian Hibah Bersaing). Surabaya: Lembaga Penelitian Universitas Airlangga175

Susanto, A. (2011). Perkembangan Anak Usia Dini (Pengantar dalam Berbagai Aspeknya). Jakarta: Kencana

Wylie, C. (1998). Six Years Old and Competent: The Secon Stage of the Competent Cildren Project-A summary of the main Findings. Wellington, NZ: New Zealand Council for Educational Research.

Zainuddin, M. (2011). Metode Penelitian Kefarmasian dan Kesehatan. Surabaya: Airlangga University Press. 